\title{
PENGEMBANGAN USAHA PENGRAJIN ANYAMAN ROTAN DI DESA LUWOO, KECAMATAN TELAGA JAYA, KABUPATEN GORONTALO
}

\author{
Ayuddin $\left.{ }^{1 *}\right)$, Ansar $^{2}$ \\ 1)Program Studi Teknik Sipil, Universitas Negeri Gorontalo \\ 2)Program Studi Manajemen Pendidikan, Universitas Negeri Gorontalo \\ Jalan Jenderal Sudirman No. 6 Kota Gorontalo \\ *alamat korespondensi: ayuddin_ung@rocketmail.com
}

\begin{abstract}
ABSTRAK
Usaha Pengrajin anyaman rotan (UD. ROTAN INDAH) yang berdomisili di $\mathrm{Jl}$. Cempaka Desa Luwoo, Kecamatan Telaga Jaya, Kabupaten Gorontalo memproduksi berbagai anyaman rotan seperti meubel rotan (kursi dan meja), anyaman tas (handbag), assesories (hiasan), tirai rotan, barang souvenir, rangka parsel, tempat tidur bayi, dan rangka karangan bunga. Berdasarkan survei dan wawancara yang telah dilakukan bahwa dari sekian produk anyaman rotan yang diproduksi oleh UD. ROTAN INDAH hanya produk meubel rotan yang masih bertahan sampai sekarang walaupun produksinya semakin hari semakin kurang diminati oleh masyarakat Kabupaten Gorontalo dan sekitarnya. Pelaksanaan kegiatan pengabdian ini fokus pada pemecahan masalah meubel rotan (Kursi dan Meja) dengan tujuan melakukan redesain yang memperhatikan kursi dan meja yaitu konsep nilai artistik, konsep nilai fungsional, dan konsep kekuatan konstruksinya. Hasil kegiatan pengabdian masyarakat ini menghasilkan kursi dan meja berbahan rotan variasi eceng gondok dengan memodelisasi model perkuatan struktur kursi dan meja untuk bisa bertahan jangka panjang. Dengan konsep maksimal variasi rotan dengan eceng gondok diyakini akan menghasilkan produk meubel rotan (kursi dan meja) lebih inovatif, kuat, memiliki estetika yang lebih tinggi, dan lebih diminati oleh masyarakat.
\end{abstract}

Kata Kunci: Pengrajin anyaman rotan, eceng gondok, nilai artistik.

\section{PENDAHULUAN}

Kabupaten Gorontalo tergolong kelompok IKM (Industri

merupakan salah satu wilayah di Kecil dan Menengah) berdasarkan Provinsi Gorontalo yang memiliki standart yang ditetapkan oleh potensi ekonomi yang sangat Departemen perindustrian dan memadai. Potensi masyarakat perdagangan (2002). Industri IKM ini kabupaten Gorontalo selain bertani, berumur 38 tahun dan masih juga terdapat usaha di bidang bertahan sampai sekarang ini pengrajin anyaman rotan dan walaupun terus mengalami 
penurunan penghasilan disebabkan kompetitor semakin kuat disertai berkembangnya bahan-bahan lainnya seperti kayu, alumunium, dan besi.

Dalam mengembangkan industri anyaman rotan, maka IKM ini telah merancang Visi dan Misi maupun Tujuan terbentuknya suatu industri. Visi dari IKM ini adalah menginginkan suatu industri menuju IKM mandiri, Sedangkan Misinya adalah mengembangkan pengetahuan dibidang usaha kerajinan rotan dan seni sesuai dengan bakat, minat, dan potensi karyawan. Adapun Tujuan terbentuknya IKM ini adalah (1) Terbentuknya jaringan kerja dan kemitraan dengan pengusahapengusaha IKM, (2) Terlaksananya pemberdayaan industri kecil dan menengah dan masyarakat sekitar perusahaan yang memproduksi rotan agar berkembang dan mandiri, (3) Terbentuknya unit-unit usaha industri yang baru, (4) Terciptanya budaya kerja bagi masyarakat sekitar sehingga dapat meransang pertumbuhan inovasi-inovasi baru dalam pemanfaatan sumber daya alam yang ada disekitarnya, dan (5) Terciptanya efisiensi dan efektifitas produksi anyaman rotan.

Produk anyaman rotan yang dihasilkan IKM ini adalah anyaman rotan tas (handbag), tirai rotan, barang souvenir, rangka parsel, rangka karangan bunga. Produk lainnya yang masih bertahan sampai sekarang ini adalah anyaman rotan kursi dan meja. Produksi-produksi yang dihasilkan sebagai berikut:

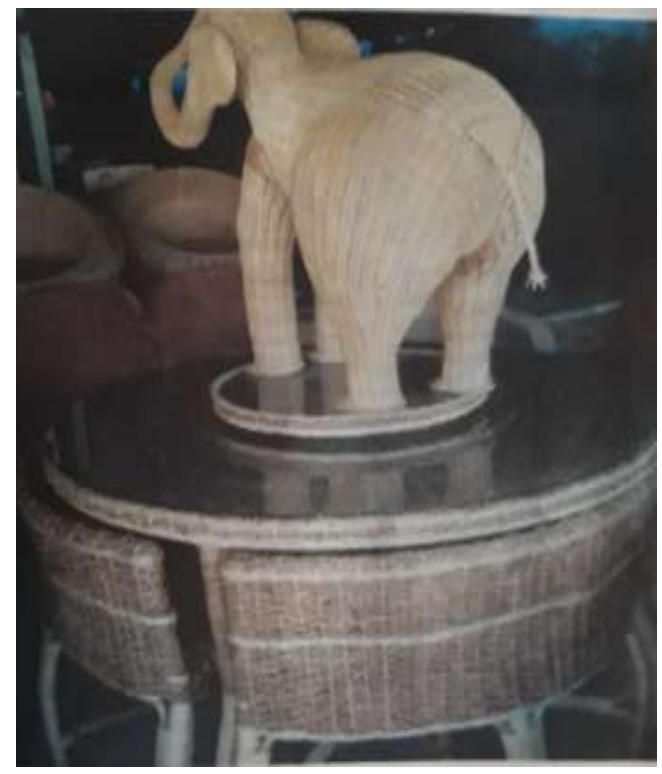

Gambar 1. Meja dan Hiasan Rotan

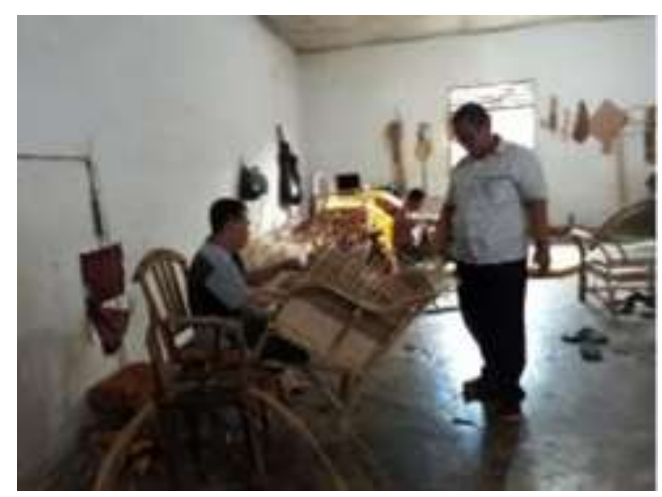

Gambar 2. Rangka Kursi dan Meja

Anyaman rotan seperti ini sudah sangat lambat pembelinya. Anyaman rotan ini dikategorikan produk yang tidak bersaing lagi dengan produk dari bahan lainnya (Departemen Perdagangan, 2008). Salah satu sebab adalah (1) Model desain dan kekuatan yang ditampilkan tidak menarik dan tidak mampu bersaing dengan produk dari bahan lainnya seperti alumunium, 
kayu, dan besi, (2) Percepatan proses bekerja tenaga kerja sangat lambat dan sistem pemasarannya pun tidak maksimal, (3) Sistem jaringan pemasaran yang digunakan adalah sistem jaringan konvensional yaitu pesanan langsung dari berbagai toko meuble di kabupaten gorontalo dan sekitarnya termasuk kota gorontalo, (4) Salah satu penyebab juga adalah sangat lama diproduksi karena berbagai tahapan proses yang dilakukan dan alat pun yang digunakan tergolong manual yang digunakan saat ini, bekerja kurang efektif dan efesien sehingga hasilnya kurang maksimal. Hal ini karena alat yang digunakan terutama pelengkung rotan masih menggunakan bara api yang dibantu dengan tangan. Dengan demikian, jumlah produk kursi dan meja yang dipasarkan kepada toko rata-rata sebesar 12 set per bulan. Tetapi kenyataannya tidak semuanya dibeli oleh masyarakat karena saingan di bidang pembuatan kursi dan meja sangat banyak khususnya yang menggunakan bahan non rotan lainnya seperti kayu, besi, dan alumunium.

Dengan demikian, untuk menaikkan daya beli buyer, maka dalam pengabdian ini dilakukan bimbingan khusus, strategi pekerjaan, dan rancangan desain yang kuat dan bernilai artistik dengan harapan dapat membantu kelancaran produksi IKM ini, sehingga kapasitas industri yang sedianya hanya memproduksi 12 set kursi dan meja perbulannya, akan mampu meningkat produksinya minimal sekitar 50 \% per bulan. Dengan jalan ini, seluruh pekerja dan pemilik usaha dapat meningkat penghasilannya dengan pekerjaan yang efektif dan efisien.

Tujuan dari metode pelatihan ini adalah :

1. Untuk menanamkan kecakapan, ketrampilan teknis, dan praktis dalam membuat kursi dan meja dari rotan variasi eceng gondok yang memiliki nilai keindahan yang tinggi,

2. Memberikan gambaran konkrit di tempat kerja tentang teknik pembuatan kursi dan meja dari rotan variasi eceng gondok.

3. Untuk menghasilkan kursi dan meja dari rotan variasi eceng gondok yang dapat bersaing dengan pengusaha kursi dan meja yang menggunakan bahan non rotan seperti kayu, alumunium, dan besi .

4. Mencipatkan lapangan kerja yang berkelanjutan, dan

5. Dapat meningkatkan pendapatan usaha Pengrajin anyaman rotan variasi eceng gondok.

\section{METODOLOGI}

\section{Flowchart Pelaksanaan}

Pelaksanaan

kegiatan dilakukan melalui beberapa tahapan, seperti ditunjukkan pada Gambar 3. 


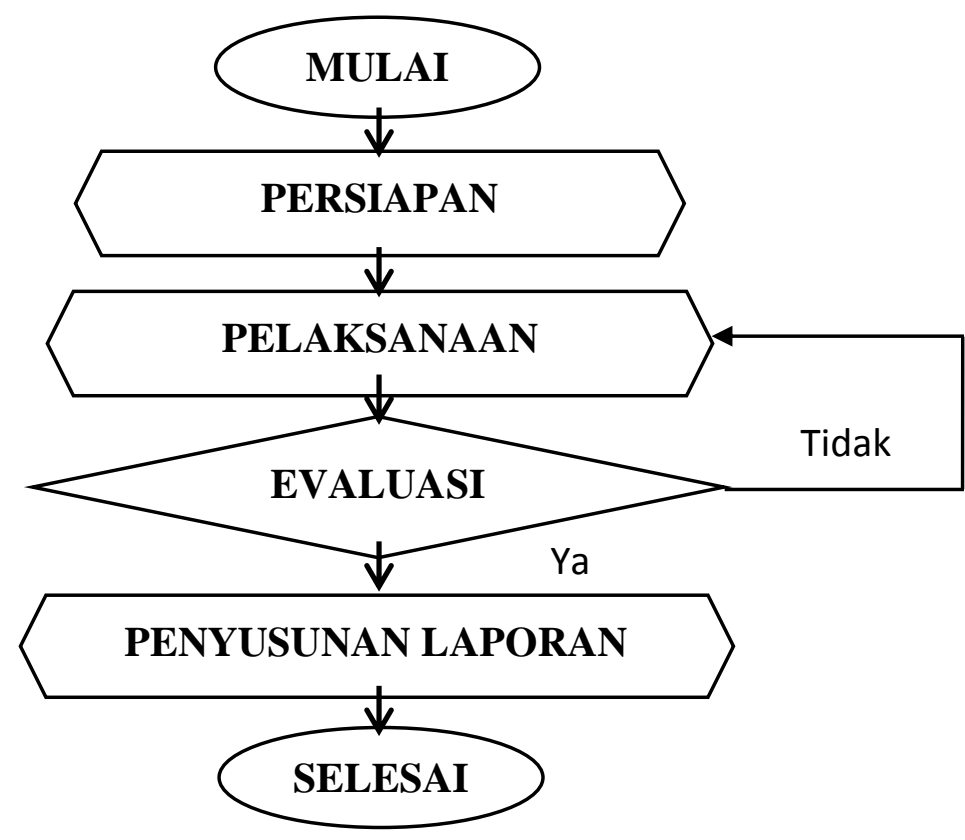

Gambar 3. Diagram Alir Pelaksanaan

Metode yang digunakan dalam menyelesaikan masalah melalui program PKM ini adalah metode pelatihan secara langsung (training), demonstrasi percobaan, dan pembinaan pengembangan usaha terhadap pengrajin rotan variasi eceng gondok.

\section{Penjabaran Kegiatan}

Tahapan Kegiatan

Kegiatan PKM pengabdian kepada masyarakat ini melalui beberapa tahapan, meliputi :

a. Persiapan

- Survei tempat pelaksanaan kegiatan PKM, dalam hal ini adalah Desa Luwoo Kecamatan Telaga Jaya Kabupaten Gorontalo.
- Wawancara

dilakukan kelompok pengrajin rotan kursi dan meja dengan tujuan untuk keperluan pelatihan yang akan dilakukan dan mengarahkan mengikuti model yang sudah didesain.

- Pembuatan materi pelatihan

Materi pelatihan ini berkaitan dengan model yang akan diikuti dan pengembangan model-model lainnya. Materi ini juga diajarkan cara melengkung rotan, menganyam rotan, dan memperhitungkan aspek kekuatannya (Januminro, 2000).

b. Pelaksanaan kegiatan

Rencana pelaksanaan kegiatan dibagi menjadi beberapa tahap, 
yang akan dibahas dibab selanjutnya.

c. Evaluasi

Tahapan ini dilakukan untuk mengetahui tingkat keberhasilan kegiatan, sehingga dapat dilakukan penyempurnaan apabila terdapat kekurangan didalamnya. Evaluasi ini bertujuan untuk mengetahui apakah terdapat peningkatan kerja baik dari segi metode maupun pengembangan kreativitas pengrajin dengan memperhitungkan tiga konsep utama, yaitu: efesiensi, estetis, dan fungsional.

d. Penyusunan laporan kemajuan dan laporan akhir dari kegiatan pengabdian PKM yang dilaksanakan.

\section{HASIL DAN PEMBAHASAN}

Pada kegiatan pengabdian masyarakat dilakukan percobaan atau demonstrasi setelah dilaksanakan pelatihan teknik pembuatan meja berdasarkan Ayuddin (2017) dan kursi dari rotan. Pengrajin rotan ini dibimbing dan dibina yang berkenaan dengan materi pelatihan. Selanjutnya dilakukan demonstrasi percobaan yang mencakup: Cara pembuatan rangka yang memperhatikan nilai artistik, kekuatan rangka, dan penempatan rotan secara fungsional. Di samping itu, dalam meningkatkan pendapatan, kelompok pengrajin rotan sebagai usaha mitra juga diberi keterampilan mengenai strategi memodifikasi desain yang memperhatikan efisiensi, estetis, dan fungsuional.

Tabel 1. Ketercapaian Target Luaran

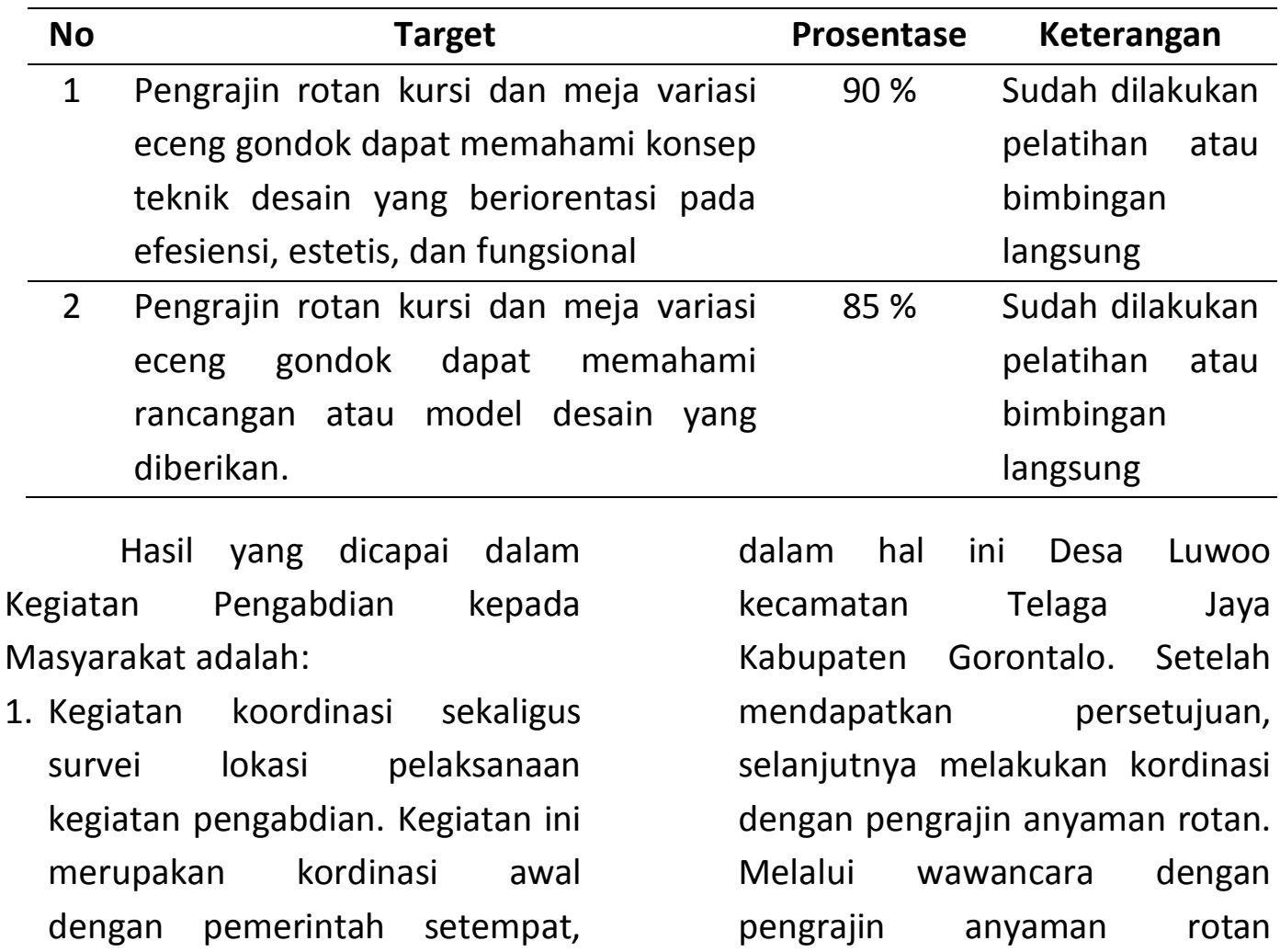




$\begin{array}{lr}\text { diperoleh informasi } & \text { tentang } \\ \text { pemahaman dan kreativitas } \\ \text { pengrajin }\end{array}$
perkembangan model kursi dan meja. Selama ini pengrajin kesulitan dalam mengembangkan konsep dan model desain yang bisa diminati masyarakat. Para pengrajin kursi dan meja rotan tersebut sangat berat bersaing dari pengrajin anyaman rotan yang terbuat dari kayu maupun alumunium. Disadari juga, sulitnya memasarkan karya kursi dan meja yang dihasilkan dari rotan tersebut.

Hasil kordinasi dengan pengrajin disepekati untuk dilakukan pelatihan yang menghasilkan model yang bisa bersaing dengan desain bahan lainnya yang ada di pasaran.

2. Penyiapan alat dan bahan untuk pelatihan pembuatan kursi dan meja dari anyaman rotan divariasikan dengan eceng gondok.

Dari hasil kordinasi, tim pelaksana menyiapkan materi pelatihan dengan memperhatikan usulan berbagai pengrajin anyaman rotan kursi dan dari kelurahan Luwoo kecamatan Telaga Jaya Kabupaten Gorontalo. Materi yang diberikan dalam pelatihan diantaranya: Materi ilmu desain, pemilihan model, cara pembuatan, pelatihan teknik dan strategi dalam melengkung rotan untuk dilakukan pemodelan dalam pembuatan kursi dan meja dari rotan.

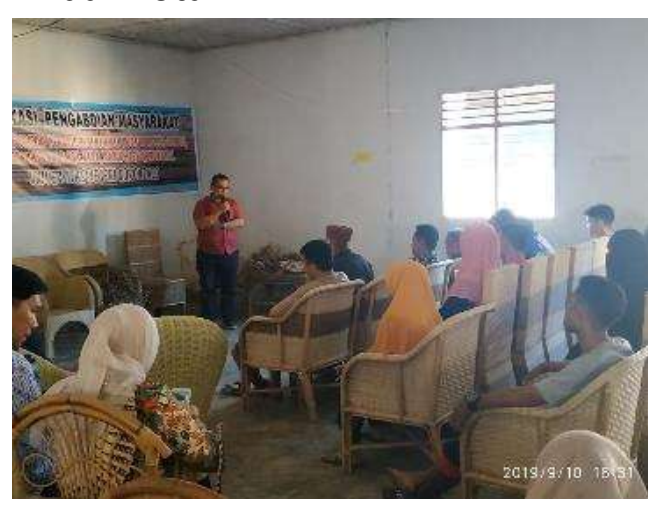

Gambar 4. Pembekalan Gagasan kepada Pengrajin Anyaman Rotan

3. Pelaksanaan Pelatihan

Pelaksanaan pelatihan diawali dengan pemaparan konsep dan strategi membuat kursi dan meja yang terbuat dari rotan. Bahan rotan yang elastis menjadi awal pemahaman dalam merancang dan membentuk sesuai model yang diinginkan. Dalam kegiatan pelatihan ini, pengrajin anyaman rotan dalam pembuatan kursi dan meja diberikan beberapa bekal ilmu pengetahuan dalam menyelesaikan model rancangan dari PKM ini. Beberapa bekal pelatihan yang diberikan, diantaranya:

a. Membuat rangka kursi dan meja dari rotan dan eceng gondok

Dalam membuat rangka diawali dengan pengukuranpengukuran dan besaran rotan sesuai model. Ukuran 
besar dan kecil adalah bahagian yang diinginkan dari nilai keindahan yang ditampilkan. Setelah

dilakukan pengukuran dan besaran rotan yang diinginkan, maka nilai kekuatan juga harus dipertimbangkan sehingga dudukan kursi dan meja dari anyaman rotan dan anyaman rotan bisa lebih kokoh dan bertahan lama.

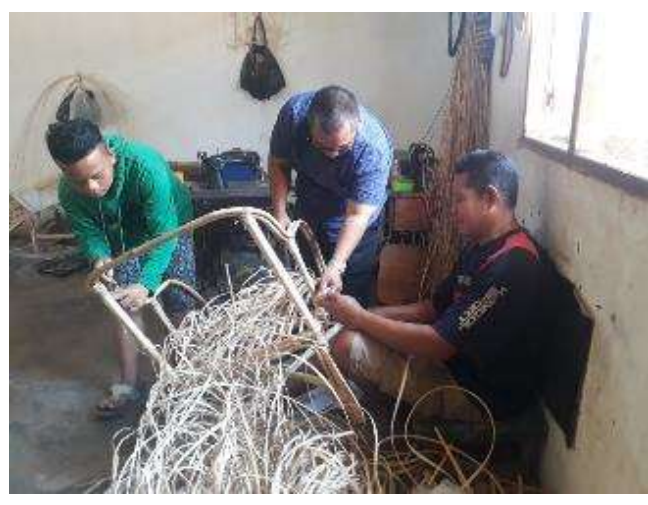

Gambar 5. Pelatihan ketelitian mengukur model rangka

b. Cara melengkung rotan Rotan memiliki keunggulan apabila dimanfaatkan untuk pembuatan kursi dan meja karena bahan rotan bisa didesaian dengan model simpel dan lengkungan yang diinginkan. Dalam pelatihan ini diberikan bekal kepada pengrajin tentang cara melengkung atau membengkokkan rotan sehingga menghasilkan keleluasan bentuk sesuai dengan keinginan. IImu pengetahuan ini sangat

penting dimiliki oleh pengrajin rotan karena merupakan bahagian dari konsep yang memperhitungkan gaya-gaya yang bekerja di dalamnya sehingga memiliki kesatuan dan terpenuhinya elemenelemen desain. Rotan bisa dimodel atau dilengkungan sesuai dengan desain yang diinginkan sehingga dapat up to date menyesuaikan dengan trend yang berkembang dan tidak kelihatan kaku. Cara melengkung butuh kreativitas dan seni yang tinggi walaupun alat yang digunakan sangat sederhana dan dilakukan dengan cara manual seperti pada gambar 6 yang dipraktekkan saat pelatihan.

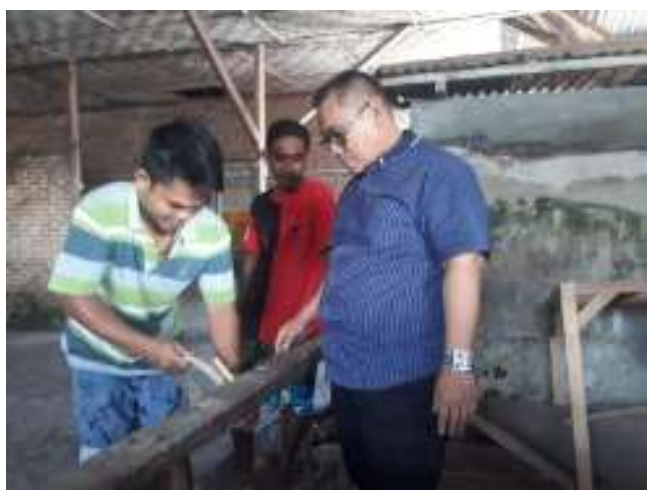

Gambar 6. Cara melengkung rotan Model

c. Cara menganyam rotan Dalam pelatihan ini, juga dilakukan

proses 
menganyam rotan yang tergolong sangat sulit dan membutuhkan kesabaran yang tinggi oleh pengrajin rotan karena harus dilakukan dengan teliti dan proses yang panjang. Tujuan dari proses penganyaman ini untuk menutupi kerangka kursi yang disesuaikan dengan desain yang dirancang. Dalam proses penganyamannya

menggunakan rotan polis untuk menghasilkan anyaman yang indah. Rotan polis diartikan sebagai jenis rotan yang sudah dibersihkan kulitnya atau dengan kata lain yang biasa disebut dengan rotan putih. Dalam pelatihan ini dilakukan dengan tahapan pekerjaan yang diwali dengan penganyaman secara horizontal. Cara ini dimaksudkan untuk menentukan jarak dan landasan permukaan yang diinginkan. Selanjutnya, dilakukan dengan tahap penganyaman secara vertikal. Gunanya ialah untuk membuat hasil anyaman yang kuat dimana saling mengikat dan menyatu dengan baik di landasan permukaan kursi. Cara ini merupakan cara yang sederhana tetapi memiliki kekuatan yang sangat tinggi sehingga dalam jangka waktu yang panjang bisa bertahan lama. Cara penganyaman yang dilakukan di lapangan saat pelatihan khusus kepada pengrajin diperlihatkan pada Gambar 7. di bawah.

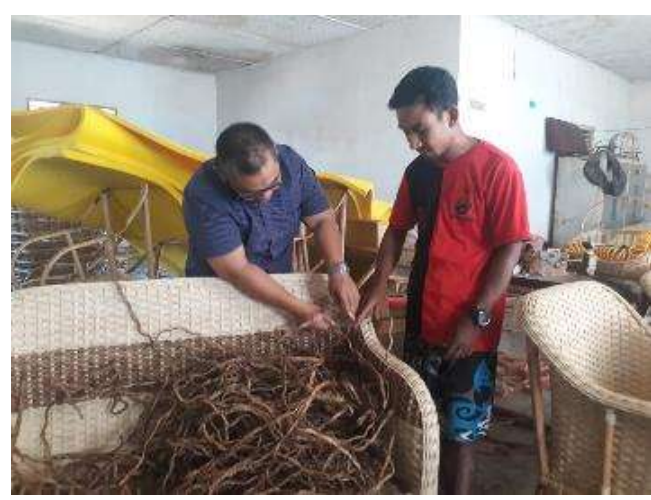

Gambar 7. Cara Menganyam Eceng Gondok

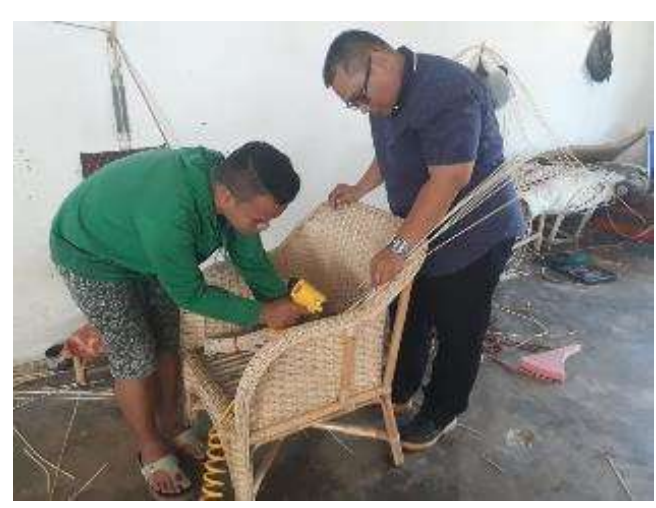

Gambar 8. Cara Menjepit anyaman Rotan di Kursi

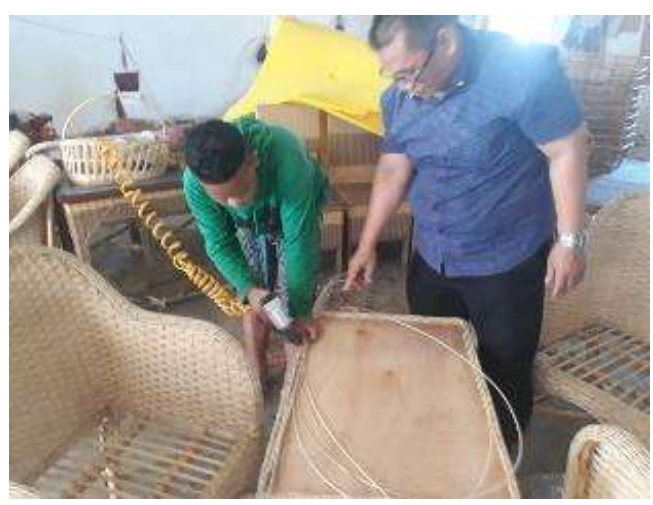


Gambar 9. Cara Menjepit Anyaman Rotan di Meja

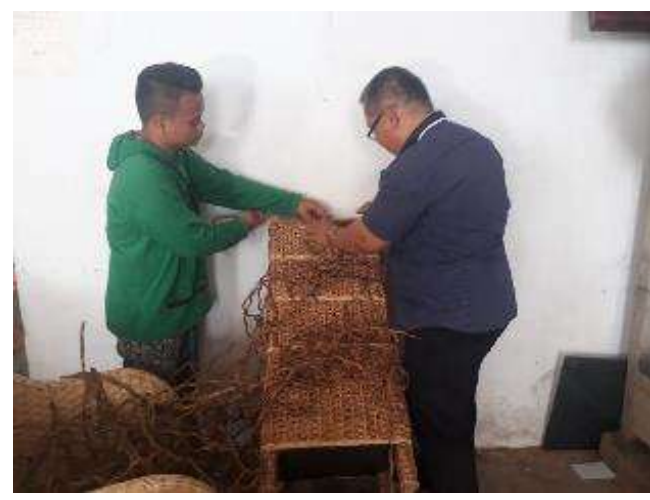

Gambar 10. Cara Menganyam Eceng Gondok di bagian Sudut Kursi

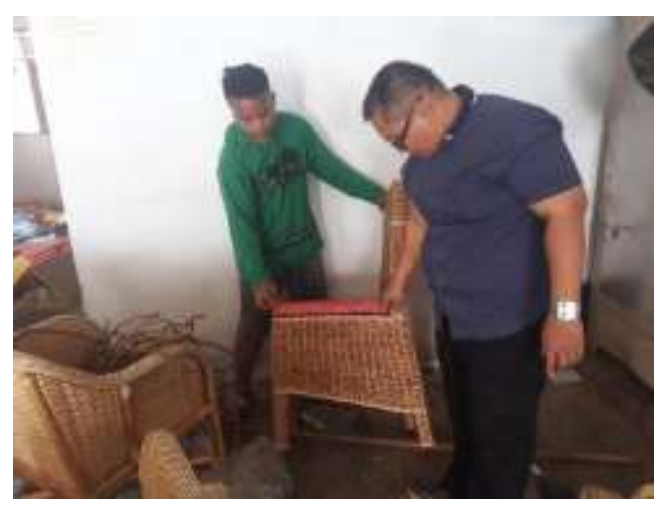

Gambar 11. Cara Menjepit Pelapis Dudukan

4. Refleksi Hasil Penelitian

Selama proses pelatihan dan bimbingan langsung kepada kelompok pengrajin kursi dan meja dari rotan. Pengrajin sangat antusias mengikuti tahapan pelatihan yang diberikan oleh instruktur dengan beberapa pokok bahasan yang terkait dengan penggunaan rotan variasi eceng gondok untuk kursi dan meja. Dalam pemantauan tim pelaksana kegiatan pengabdian melihat secara langsung pekerjaan sekaligus melakukan wawancara terhadap isi materi, metode dan cara pemaparan instruktur dalam memperkenalkan model desain dan pengembangan inovasiinovasi terbaru untuk bersaing dengan material lain seperti kayu, alumunium maupun besi untuk pembuatan kursi dan meja. Tanggapan peserta terhadap materi pelatihan yang diberikan dapat dilihat pada gambar 12 di bawah dan tanggapan peserta terhadap instruktur diperlihatkan pada gambar 13 di bawah.

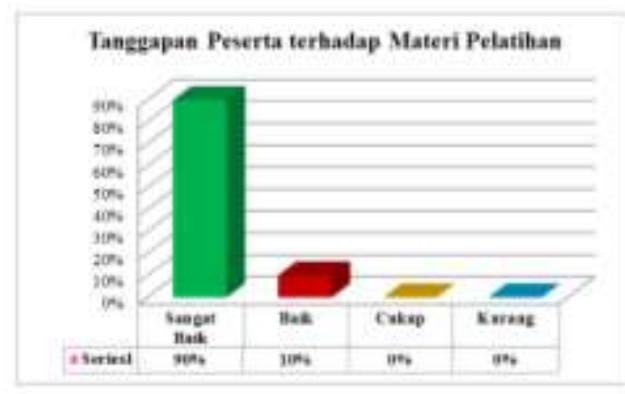

Gambar 12. Tanggapan Peserta terhadap Materi Pelatihan

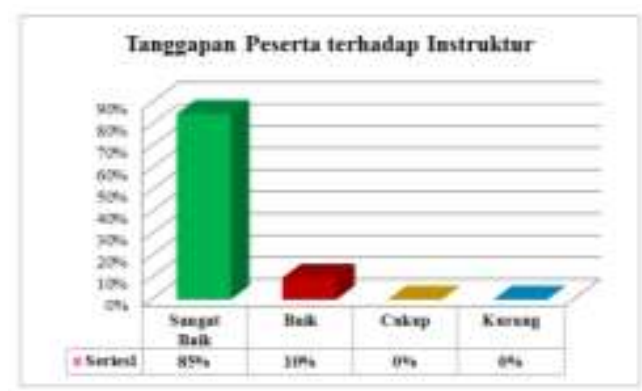

Gambar 13. Tanggapan Peserta terhadap Instruktur 


\section{KESIMPULAN DAN SARAN}

Pelaksanaan pengabdian kepada masyarakat pada skema Program Kemitraan Masayarakat (PKM) tahun anggaran 2019 yang diawali dengan pemaparan konsep atau model desain kursi dan meja. Hasil pengabdian ini telah dilakukan pelatihan dan bimbingan langsung kepada pengrajin rotan. Pengrajin rotan sebagai peserta bimbingan pelatihan telah merenspon baik upaya yang dilakukan oleh instruktur baik isi materi maupun cara penyajiannya. Respon para kelompok pengrajin anyaman rotan sangat tinggi terhadap isi materi pelatihan yang diberikan yaitu mencapai $90 \%$ dan cara penyajian maupun konsep desain atau model yang ditampilkan dengan beberapa strategi pekerjaan dengan memperhitungkan tiga konsep yaitu efisiensi, estetis, dan fungsional juga responnya sangat tinggi yaitu mencapai 85 \%. Ini menunjukkan bahwa sangat tinggi minat para pengrajin anyaman rotan variasi eceng gondok untuk mengembangkan usahanya dengan merubah model atau desain yang dapat diminati oleh masyarakat.

\section{UCAPAN TERIMA KASIH}

Penulis haturkan terima kasih kepada Direktorat Riset dan Pengabdian Masyarakat Direktorat Jenderal Penguatan Riset dan
Pengembangan Kementrian Riset, Teknologi dan Pendidikan Tinggi (Kemenristek Dikti) yang telah memberikan dana hibah pengabdian masyarakat 2019 (PKM).

\section{DAFTAR PUSTAKA}

Direktorat Pengembangan Kawasan Khusus dan Tertinggal. 2004. Panduan Pembangunan Klaster Industri Untuk Pengembangan Ekonomi Daerah Berdaya Saing Tinggi. Jakarta: Bappenas.

Departemen Perindustrian dan Perdagangan. 2002. Rencana Induk Pengembangan Industri Kecil Menengah. Departement Perindustrian dan Perdagangan Republik Indonesia.

Departemen Perdagangan. 2008. Pengembangan Industri Pengolahan Rotan Indonesia. Biro Umum dan Humas. Jakarta.

Januminro CFM. 2000. Rotan Indonesia. Yogyakarta: Kanisius.

Ayuddin. 2017. IBM Pengrajin Meja dan Kursi di Kelurahan Buladu Kota Gororntalo. Jurnal Penelitian dan Pengabdian Masyarakat ETHOS: 97-104. 